\title{
Inferences from stable water isotopes on the Holocene evolution of Scharffenbergbotnen blue-ice area, East Antarctica
}

\author{
Anna SINISALO, ${ }^{1,2}$ Aslak GRINSTED, ${ }^{1,2}$ John C. MOORE, ${ }^{1}$ Harro A.J. MEIJER, ${ }^{3}$ \\ Tõnu MARTMA, ${ }^{4}$ Roderik S.W. VAN DE WAL ${ }^{5}$ \\ ${ }^{1}$ Arctic Centre, University of Lapland, PO Box 122, FIN-96101 Rovaniemi, Finland \\ E-mail: anna.sinisalo@ulapland.fi \\ ${ }^{2}$ Department of Geophysics, Box 3000, University of Oulu, FIN-90014 Oulu, Finland \\ ${ }^{3}$ Centre for Isotope Research (CIO), University of Groningen, Nijenborgh 4, 9747 AG Groningen, The Netherlands \\ ${ }^{4}$ Institute of Geology, Tallinn University of Technology, 7 Estonia Avenue, EE-10143 Tallinn, Estonia \\ ${ }^{5}$ Institute for Marine and Atmospheric Research Utrecht, Utrecht University, 3508 TA Utrecht, The Netherlands
}

\begin{abstract}
We show that it is possible to extract a high-resolution (annual) paleoclimate record from the surface of a blue-ice area (BIA). The variability of the surface stable-isotope values suggests that almost all the surface ice in Scharffenbergbotnen BIA, East Antarctica, is of Holocene age. The isotopic changes across the BIA show that the modern climate there is warmer than the climate in the earlyHolocene optimum (11 kyr BP). A volume-conserving ice flow model for the BIA constrained by isotopic variability and layer thicknesses, and a series of ${ }^{14} \mathrm{C}$ ages indicate both that the BIA has been smaller than now, and that the surface velocities were considerably smaller during the Last Glacial Maximum. Changes in ice-sheet thickness drive the BIA towards present-day conditions. The relatively young age of the majority of the BIA also explains the lack of meteorite finds in this area, and may be typical for many BIAs in low-elevation nunatak areas.
\end{abstract}

\section{INTRODUCTION}

Antarctic blue-ice areas (BIAs) are known to have old ice at the surface (e.g. Whillans and Cassidy, 1983; Nishiizumi and others, 1989; Bintanja, 1999). Ablation in Antarctic blue-ice areas above $1000 \mathrm{~m}$ is overwhelmingly dominated by sublimation rather than melting (Bintanja, 1999). Such ice is likely to contain a high-resolution paleoclimate record that is easier to access than traditional deep ice cores. The dating of surface blue ice is, however, demanding. Previously, blue-ice samples from various BIAs have been dated by terrestrial ages of meteorites found on their surface (e.g. Whillans and Cassidy, 1983; Nishiizumi and others, 1989), by ${ }^{14} \mathrm{C}$ dating of ice (Van Roijen and others, 1995; Van der Kemp and others, 2002), by radiometric dating of tephra layers found at the surface of BIAs (Wilch and others, 1999) and by stratigraphic comparison with ice cores (Moore and others, 2006).

Isotopic composition of polar snow and ice has been regarded as a valuable temperature proxy in East Antarctica for decades (e.g. Lorius and Merlivat, 1977). Here, we make use of the ratios of heavy to light atoms of both oxygen and hydrogen expressed as $\delta^{18} \mathrm{O}$ and $\delta \mathrm{D}$ values, respectively. The deuterium-excess, $d\left(d=(\delta \mathrm{D}-8) \delta^{18} \mathrm{O}\right)$, is assumed to depend mainly on the physical conditions in the source area for mid- and high-latitude precipitation. Changes in $d$ are traditionally used as indicators of changes in the average temperature of oceanic moisture sources (Merlivat and Jouzel, 1979; Petit and others, 1991; Vimeux and others, 2001). However, Helsen and others (2006) showed that the vertical gradient in $d$ excess over the moisture source area and the kinetic fractionation along the transport path have a prominent influence on the observed $d$ values.

There are very few paleoclimate data records from Antarctic BIAs. The only continuous horizontal stableisotope record, i.e. a $\delta^{18} \mathrm{O}$ record extracted from an ice sample cut from the surface of a BIA along the flowline, has been extracted from Mount Moulton $\left(76^{\circ} \mathrm{S}, 135^{\circ} \mathrm{W}\right.$; $2800 \mathrm{~m}$ a.s.l.) and covers 140000 years (Popp and others, 2004). However, this record does not include the Holocene since that part of the BIA was covered by snow when sampling was done.

Here we focus on the surface blue ice in Scharffenbergbotnen BIA, Dronning Maud Land (DML), $\left(74^{\circ} \mathrm{S}, 11^{\circ} \mathrm{W}\right.$; $1200 \mathrm{~m}$ a.s.l.), where there is some uncertainty in the dating. Some authors argue that glacial ice is present at the eastern end of the valley (Van Roijen, 1996; Grinsted and others, 2003), but others have suggested, in general terms, that BIAs in DML may have been an accumulation area during the glacial period (Bintanja, 1999). In this paper, we show that almost all the surface ice in the area is Holocene, based on the variability of the stable-isotope values. We study the spatial and temporal isotopic changes in the BIA in terms of climate variability, and compare results with other East Antarctic sites. Finally, we show results of a simple model on how the dynamics of the BIA may have evolved since the Last Glacial Maximum (LGM).

\section{BACKGROUND}

\subsection{Study area}

Scharffenbergbotnen (Fig. 1) is the best-studied Antarctic BIA. It is a valley located in the Heimefrontfjella mountain range at the edge of the Antarctic plateau about $350 \mathrm{~km}$ from the coast. Several studies have been made of its mass balance (Jonsson and Holmlund, 1990; Jonsson, 1992; Sinisalo and others, 2003), ice flow and surface age distribution (Van Roijen, 1996; Grinsted and others, 2003; Sinisalo and others, 2004), on the blue-ice surface properties (Bintanja and others, 2001) and on the moraines in the area (Lintinen and Nenonen, 1997; Hättestrand and Johansen, 2005). 


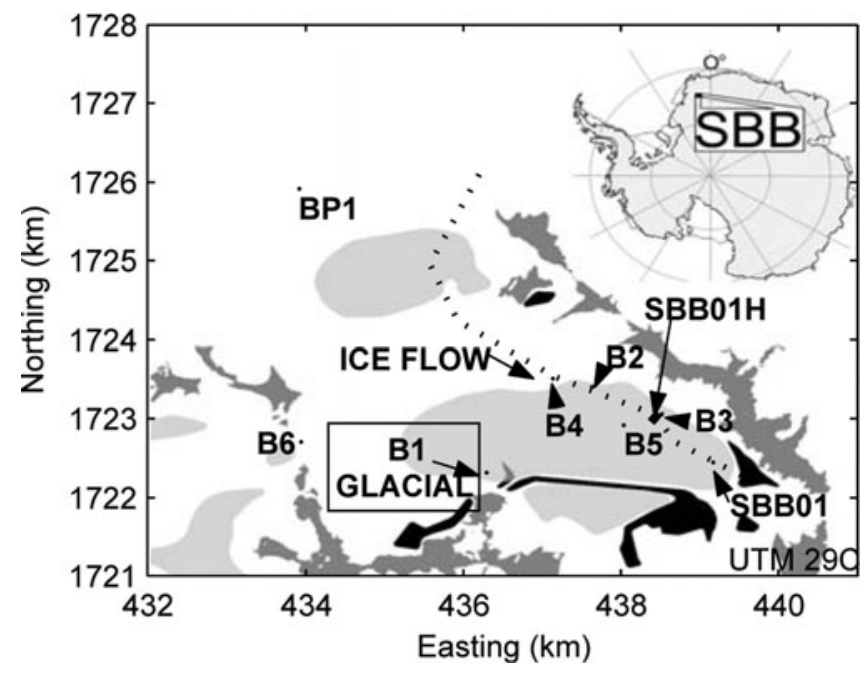

Fig. 1. Locations of the shallow blue-ice cores (B1-B5), firn core (B6), snow pit (BP1), the $100 \mathrm{~m}$ horizontal ice core $(\mathrm{SBB} 01 \mathrm{H})$ and the $52 \mathrm{~m}$ vertical core (SBB01) in Scharffenbergbotnen (SBB). Supraglacial moraines are marked in black, mountains in dark gray and blue ice in light gray. The ice flow is from northeast into the valley (dotted line). The ice passes through a small BIA and then terminates in the main BIA close to SBB01.

The meteorological conditions in the valley and surrounding area are described in detail by, for example, Bintanja and Van den Broeke (1995a, b), Bintanja (2000a, b), Bintanja and Reijmer (2001) and Reijmer (2001). The annual average temperature is about $-20^{\circ} \mathrm{C}$ and wind speed is $\sim 7 \mathrm{~m} \mathrm{~s}^{-1}$ (Reijmer, 2001). Scharffenbergbotnen is located in the lee side of the nunataks, and geostrophically and katabatically forced winds blow from easterly directions (Bintanja, 2000b). The precipitation is characterized by a highly intermittent accumulation record (Reijmer and Van den Broeke, 2003) with large spatial variations in the valley (Sinisalo and others, 2003). The present-day moisture source area is in the southern Atlantic Ocean (Reijmer, 2001; Helsen and others, 2006).

The meteorological conditions over the BIA differ from those over the snow-covered surroundings as the air over the $\mathrm{BIA}$ is warmer and the relative humidity is lower than over a snow site (Bintanja and Reijmer, 2001). These conditions contribute to the observed high sublimation rates of blue ice. Surface sublimation over the BIA is significantly higher than over snow (Bintanja and Reijmer, 2001), being $>0.1 \mathrm{~m}$ w.e. $\mathrm{a}^{-1}$ at the southeastern end of the valley (e.g. Sinisalo and others, 2003). Slight surface melting occurs during a few high-insolation days in the BIA. The surface water film, however, is subsequently refrozen and removed by sublimation.

The main BIA in Scharffenbergbotnen is of the closed type, i.e. the ice has no outflow from the valley (Grinsted and others, 2003), and therefore it must have old ice at the surface if it is in steady state. According to geomorphological studies of Hättestrand and Johansen (2005), the difference between the surface elevation in Scharffenbergbotnen and outside the valley is greater today than when the ice sheet was thickest, which probably occurred during the LGM. The debris cover of the supraglacial moraines on the surrounding slopes in and outside Scharffenbergbotnen suggests that the ice surface in the valley was $200-250 \mathrm{~m}$ higher, and the elevation of the surrounding ice sheet only 50-150 m higher, at the LGM than today (Hättestrand and Johansen, 2005). The elevation decrease in the valley probably occurred gradually after the surrounding ice-sheet elevation had decreased after the LGM and ice overflow of the nunataks at the eastern end of the valley became insignificant. A decrease in surface elevation relative to the surrounding nunataks results in stronger katabatic flow, which has a positive feedback to the extent of a BIA (Van den Broeke and Bintanja, 1995). The moraine structures strongly suggest that the inner part of Scharffenbergbotnen must have been a local ablation area during the LGM; i.e. a BIA has long existed in the valley (Hättestrand and Johansen, 2005).

\subsection{Sample locations}

A $52 \mathrm{~m}$ long vertical ice core (SBB01 in Fig. 1) was drilled in the innermost part of the valley close to the end of the current flowline during the austral summer of 1997/98 (R. Bintanja and others, unpublished information). A $100 \mathrm{~m}$ horizontal ice core $(\mathrm{SBB} 01 \mathrm{H}$ in Fig. 1) was collected, using electric chainsaws, from the surface of the BIA $1 \mathrm{~km}$ upstream from SBB01 in 2003/04. Approximately the top $20 \mathrm{~cm}$ was cut off from the samples in order to remove a possible refrozen meltwater layer in the high-insolation period, and to avoid any other disturbances from surface processes that may have influenced the ice composition.

In addition, a $10 \mathrm{~m}$ firn core (B6) and five $3 \mathrm{~m}$ shallow cores (B1-B5) were drilled in the austral summer 1999/2000 (Fig. 1). In the same field season, a $2 \mathrm{~m}$ snow pit (BP1) was also sampled at the northwestern entrance to the valley (Fig. 1). The details of the subsampling of the blue-ice cores and snow and firn samples are collated in Table 1.

\subsection{Previous dating of Scharffenbergbotnen blue ice}

Several blue-ice samples were dated using the ${ }^{14} \mathrm{C}$ method described by Van Roijen and others (1994) and Van der Kemp and others (2002) and converted to calendar ages using the radiocarbon calibration curve of Reimer and others (2004). The surface ages at the main BIA varied between 4000 and 14000 years along the flowline (Fig. 1). These ages, however, have large uncertainties of up to several thousands of years. The ${ }^{14} \mathrm{C}$ age for the uppermost $45 \mathrm{~m}$ section of the SBB01 is $9300 \pm 400$ years (Van der Kemp and others, 2002) which corresponds to a calibrated calendar age of $10500(+700$, $-300)$ years. Unfortunately, a vertical age span cannot be determined for the ice core from the ${ }^{14} \mathrm{C}$ data.

Van Roijen (1996) used a numerical model of the ice flow in the valley based on the shallow-ice approximation and compared its results to the ${ }^{14} \mathrm{C}$ dating of the ice samples. He obtained surface ages of up to 60000 years at the end of the flowline at the eastern end of the valley using three different surface velocity and mass-balance scenarios. Grinsted and others (2003) modelled the ice flow in the valley with a volume-conserving model which assumes constant ice-sheet geometry over time, i.e. steady-state flow. The flowline (Fig. 1) was chosen based on the measured velocity data (Van Roijen, 1996; Sinisalo and others, 2003) and is more realistic than the flowline that Van Roijen (1996) used, although the differences are not crucial. Grinsted and others (2003) used the measured accumulation and surface velocities (Van Roijen, 1996; Sinisalo and others, 2003) as input parameters, and obtained very old ages ( $\sim 100000$ years) for the ice at the end of the flowline. The difference between the modelled ages is most likely due primarily to different grid resolutions at the end of the flowline where the ages are highest. 


\section{METHODS}

\subsection{Isotopic analysis}

The $\delta^{18} \mathrm{O}$ and $\delta \mathrm{D}$ analyses of the SBB01H and SBB01 cores were made at the Centre for Isotope Research, University of Groningen, The Netherlands. The $\delta^{18} \mathrm{O}$ measurements were performed with a Sira-10 isotope-ratio mass spectrometer with an adjacent $\mathrm{CO}_{2}-\mathrm{H}_{2} \mathrm{O}$ isotopic equilibrium system. The $\delta \mathrm{D}$ measurements were performed using a continuousflow system, consisting of a Eurovector chromium reduction oven coupled to a GVI Isoprime. The accuracy (combined uncertainty) of $\delta^{18} \mathrm{O}$ analysis was $\pm 0.06 \%$ and of $\delta \mathrm{D}$ $\pm 0.7 \%$. The $\delta^{18} \mathrm{O}$ analysis of the $3 \mathrm{~m}$ blue-ice cores, and the $10 \mathrm{~m}$ firn core and $2 \mathrm{~m}$ snow pit was performed at the University of Technology, Tallinn, Estonia, using a FinniganMAT Delta-E mass spectrometer. Combined uncertainty of the analyses was better than $\pm 0.1 \%$. The $\delta^{18} \mathrm{O}$ and $\delta \mathrm{D}$ are both presented with respect to the international consensus Vienna Standard Mean Ocean Water - Standard Light Antarctic Precipitation (V-SMOW-SLAP) scale (R. Gonfiantini, unpublished information). The accuracy of $d$ excess is $\pm 1.3 \%$.

\subsection{Isotopic paleothermometer}

We use the isotope record as an indicator of local temperature change in Scharffenbergbotnen and compare it with other sites from East Antarctica. Although the time-spans of the individual isotope samples from the blue-ice cores are not known, based on present-day accumulation rates (Sinisalo and others, 2003), it is plausible to assume that most of our samples span time periods of several years to centuries. Hence, the influence of seasonal extreme isotopic and temperature values that could invalidate the classical temperature interpretation of isotopic variability is minimized (Helsen and others, 2005). However, it is necessary to make corrections both for elevation changes in Scharffenbergbotnen during the Holocene and for different ocean surface isotopic composition in the early Holocene. Thus, we calculate a change in $\delta^{18} \mathrm{O}$ values due to temperature change, $\Delta \delta^{18} \mathrm{O}_{\text {temp, }}$ as

$$
\Delta \delta^{18} \mathrm{O}_{\text {temp }}=\delta^{18} \mathrm{O}_{\mathrm{m}}-\left(\Delta \delta^{18} \mathrm{O}_{\mathrm{EC}}+\gamma_{\mathrm{m}} \Delta \delta^{18} \mathrm{O}_{\mathrm{SW}}\right),
$$

where $\Delta \delta^{18} \mathrm{O}_{\mathrm{m}}$ is the difference between the average $\delta^{18} \mathrm{O}$ values measured at two sites of different age (Fig. 1), $\Delta \delta^{18} \mathrm{O}_{\mathrm{EC}}$ is the change associated with elevation change in time, $\Delta \delta^{18} \mathrm{O}_{\mathrm{SW}}$ is the change in isotopic composition of ocean surface waters in time due to deglaciation and $\gamma_{\mathrm{m}}(=0.6)$ is the temporal sensitivity of $\delta^{18} \mathrm{O}$ to the changes in marine isotopic composition (Vimeux and others, 2002; Kavanaugh and Cuffey, 2003).

In addition, there are other factors, such as changes in the water-vapor source area (Kavanaugh and Cuffey, 2003), changes in precipitation seasonality (Werner and others, 2001) and changes in the strength of the temperature inversion (Van Lipzig and others, 2002), which may have influenced isotopic changes in the Holocene. We assume here that these factors are secondary and can be discarded. We justify this assumption for some cases in section 4.2.

The decrease in surface elevation of $200-250 \mathrm{~m}$ in Scharffenbergbotnen during the Holocene (Hättestrand and Johansen, 2005) corresponds to a change of $9.3-12 \%$ in $\delta D$ $\left(1.2-1.5 \%\right.$ in $\left.\delta^{18} \mathrm{O}\right)$ using the present-day altitudinal lapse rate for $\delta^{18} \mathrm{O}$ values of $5.8 \% \mathrm{~km}^{-1}$ (Isaksson and Karlén, 1994). This lapse rate is calculated for $\delta^{18} \mathrm{O}$ values measured
Table 1. Sampling depth/length, number of subsamples $(n)$ and length of each subsample for the vertical blue-ice core B1-B5 and SBB01, for the firn core B6, the snow pit BP1 and the horizontal blue-ice core, SBB01H

\begin{tabular}{lccc}
\hline Core & Depth/length & Number of samples & Sample length \\
& $\mathrm{m}$ & & $\mathrm{cm}$ \\
\hline \multirow{2}{*}{ SBB01 } & $25.9-31.1$ & 25 & 1 \\
& & 23 & 3 \\
SBB01H & 100.4 & 10 & $18-26$ \\
& 0.6 & 87 & 2 \\
B1-B5 & $2.7-3.0$ & 27 & 2 \\
B6 & 10.0 & 4 & $2-24$ \\
BP1 & 2.1 & 28 & $2-3$ \\
& & 17 & (average 112) \\
\hline
\end{tabular}

from $10 \mathrm{~m}$ firn cores covering 15-30 years of accumulation along a traverse that crossed the Scharffenbergbotnen area. We calculate a standard error, $\sigma_{\mathrm{EC}}$, for $\Delta \delta^{18} \mathrm{O}_{\mathrm{EC}}$ of $\pm 0.1 \%$. The $\Delta \delta^{18} \mathrm{O}_{\mathrm{SW}}$ was about $+1.1 \%$ at the LGM compared with the present value (Labeyrie and others, 1987), and it was still $+0.2 \%$ at 10000 years BP (Waelbroeck and others, 2002).

The temperature change corresponding to a known $\Delta \delta^{18} \mathrm{O}_{\text {temp }}$ can be calculated using the present-day spatial isotopic temperature gradient in Antarctica as a surrogate for the temporal isotopic temperature gradient (Delaygue and others, 2000; Masson and others, 2000; Jouzel and others, 2003). In this study, we use an isotopic temperature gradient of $1.16 \% \mathrm{~K}^{-1}$ from Isaksson and Karlén (1994). The gradient is greater than found elsewhere in Antarctica but it is calculated for samples drilled very close to our study area. We estimate that the error, $\sigma_{\text {temp }}= \pm 0.28 \% \mathrm{~K}^{-1}$.

\section{RESULTS AND DISCUSSION}

The mean values of the stable-isotope ratios, $\delta^{18} \mathrm{O}$, and the population standard deviations (in \%o) for each core or pit are presented in Figure 2. The confidence interval (at 95\% level) was less than $\pm 0.7 \%$ for all the $\delta^{18} \mathrm{O}$ mean values. Table 2 shows measured $\delta^{18} \mathrm{O}$ and $\delta \mathrm{D}$ values and the population standard deviations (in \%o) for SBB01 and SBB01H.

\subsection{Age estimation of blue ice}

Different climatic periods have different signatures in stable isotopes (e.g. Petit and others, 1999). We determine whether the samples at a given site were deposited during a glacial or an interglacial period simply from the isotopic composition.

A rapid change of $\sim 40 \%$ in $\delta \mathrm{D}\left(5 \%\right.$ in $\left.\delta^{18} \mathrm{O}\right)$ in Antarctic ice is an indicator of a change between interglacial and glacial climates (e.g. EPICA Community Members, 2006). Climate variability within the Holocene as measured along the EDML core $\left(75^{\circ} \mathrm{S}, 0^{\circ} \mathrm{E} ; 2900 \mathrm{~m}\right.$ a.s.l.), the closest deep core to the study site in East Antarctica, causes changes of $<2 \%$ in $\delta^{18} \mathrm{O}$ in the centennial-scale variability, and the maximum difference in decadal means of $\delta^{18} \mathrm{O}$ is $\sim 5 \%$ for Holocene ice (H. Oerter, http://doi.pangaea.de/10.1594/ PANGAEA.264634). The standard deviation of the $\delta^{18} \mathrm{O}$ values measured from B2-B5 in Figure 1 is $<1.8 \%$, and the difference between $\delta^{18} \mathrm{O}$ values measured from B2-B5 and the present-day value of $-28.5 \%$, taken as an average from B6 and BP1, is $<4 \%$. In addition, geomorphological 


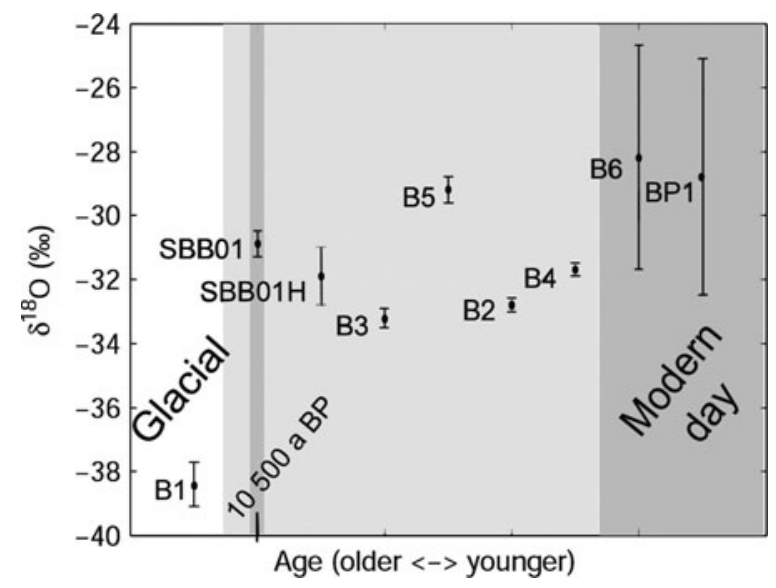

Fig. 2. Measured $\delta^{18} \mathrm{O}$ values for the shallow blue-ice cores (B1$\mathrm{B} 5)$, firn core (B6), snow pit (BP1), the $100 \mathrm{~m}$ horizontal ice core $(\mathrm{SBB} 01 \mathrm{H})$ and the $52 \mathrm{~m}$ vertical core (SBB01) marked in Figure 1 with their population standard deviations. The samples are ordered by their relative age along the $x$ axis from the sample with the oldest ${ }^{14} \mathrm{C}$ age (B1) to the firn and snow samples (B6 and BP1) representing the present-day values in the valley.

evidence suggests the blue-ice samples B2-B5 originate from a higher elevation (Hättestrand and Johansen, 2005). The correction of the elevation change would make the difference in $\delta^{18} \mathrm{O}$ values between the blue-ice samples and present-day samples even smaller. Thus, we simply conclude that most of the main BIA in Scharffenbergbotnen is of Holocene origin.

SBB01, dated at 10500 years, is located close to the bottom of the valley where the oldest surface ice along the current flowline occurs (Fig. 1). The most negative $\delta^{18} \mathrm{O}$ value measured in the valley is, however, from B1. It is $9.9 \%$ lower than the present $\delta^{18} \mathrm{O}$ value, which indicates that the ice in that particular sample, drilled from the southern margin of the main BIA (Fig. 1), originates from the glacial period. The oldest ${ }^{14} \mathrm{C}$-dated sample was found in the same part of the BIA (Van Roijen, 1996), with a calibrated calendar age of more than 28000 years BP.

In the high-resolution $\delta^{18} \mathrm{O}$ data of a $60 \mathrm{~cm}$ long section from SBB01H we clearly see three annual cycles (Fig. 3). We determine, from the power spectrum of Figure 3, that the horizontal age gradient at that location is $\sim 5.4$ years $\mathrm{m}^{-1}$. The result agrees with the surface age gradient of 3-6 years $\mathrm{m}^{-1}$ determined by dating of internal radar reflection horizons close to the current blue-ice/snow transition zone along the flowline (Sinisalo and others, 2004). This was the only highresolution section of the $\mathrm{SBB} 01 \mathrm{H}$. The flow model of
Grinsted and others (2003) gives an almost constant surface age gradient over the BIA. It is therefore reasonable to extrapolate this age gradient over the $100 \mathrm{~m}$ horizontal ice core, SBB01H. Thus we find that the horizontal ice core covers about 540 years. Similarly extrapolating over the $1 \mathrm{~km}$ distance between SBB01 and SBB01H gives an age of about 5000 years for $\mathrm{SBB} 01 \mathrm{H}$, as the SBB01 core is dated at 10500 years BP. This age is, of course, a rough approximation and we shall return to it later in relation to the flow model.

No significant periodicities were found in the highresolution isotopic data from a $1 \mathrm{~m}$ section of the vertical core SBB01. We assume that the age-depth relationship is linear for the vertical ice core since the core penetrates only a small fraction of the total ice thickness (Herzfeld and Holmlund, 1990). The isochrones in the BIA, according to flow models, are strongly inclined at the SBB01 drilling site, which is close to the bottom of the valley where vertical flow dominates (Van Roijen, 1996; Grinsted and others, 2003). This means that the vertical core is not perpendicular to the isochrones and the annual layers seem much thicker since the core cuts them obliquely. As the ice is relatively old, we can expect it to have experienced more strain thinning of annual layers. We can also expect that diffusion will act to smooth high-frequency variability in the core, relative to the signals in SBB01H. Therefore it is not surprising that there are no high-frequency cycles present in the SBB01 core, and that the $5 \mathrm{~m}$ section of ice used to extract the mean isotopic values (Table 2) samples a large number of years.

\subsection{Low-frequency changes}

Several isotopic records from East Antarctica exhibit a clear early-Holocene optimum immediately following the end of the last ice age from 11500 to 9000 years BP (Masson and others, 2000). Thus, it is plausible to assume that 10500 year old SBB01 represents the early-Holocene optimum that is generally defined as the warmest climatic period during the Holocene. In Scharffenbergbotnen, however, our results show that the present-day climate is warmer than in the early-Holocene optimum. We use a value of $-28.5 \%$ (average from B6 and BP1; Fig. 2) for present-day $\delta^{18} \mathrm{O}$ in the valley. The change in $\delta^{18} \mathrm{O}$ between SBB01 (Table 2) and the modern level is $\sim 2.4 \%$ ( $19 \%$ in $\delta \mathrm{D})$. Equation (1) gives a $\Delta \delta^{18} \mathrm{O}_{\text {temp }}$ value of $1.2 \pm 0.2 \%$ for $\Delta \delta^{18} \mathrm{O}_{\mathrm{sW}}=0.2 \pm 0.1 \%$ and an elevation change of $225 \mathrm{~m}$. According to the isotopic temperature gradient (Isaksson and Karlén, 1994), this corresponds to a warming of $\sim 1.0 \pm 0.3^{\circ} \mathrm{C}$ since the early Holocene optimum.

In contrast to the measurements in Scharffenbergbotnen, Masson and others (2000) found an opposite change in several isotopic records in East Antarctica between the early-

Table 2. The mean values of the stable-isotope ratios $\delta^{18} \mathrm{O}$ and $\delta \mathrm{D}$ and the population standard deviations (in \%o) for the vertical blue-ice core SBB01 and the horizontal blue-ice core SBB01H, the number of the samples and calculated deuterium excess, $d$

\begin{tabular}{|c|c|c|c|c|c|c|c|}
\hline Core & Number of samples & $\begin{array}{c}\text { Mean } \delta^{18} \mathrm{O} \\
\% \text { o }\end{array}$ & $\begin{array}{c}\text { Std dev. } \delta^{18} \mathrm{O} \\
\% \text { o }\end{array}$ & $\begin{array}{c}\text { Mean } \delta \mathrm{D} \\
\%\end{array}$ & $\begin{array}{c}\text { Std dev. } \delta \mathrm{D} \\
\%\end{array}$ & $\begin{array}{c}\text { Mean } d \\
\% o\end{array}$ & $\begin{array}{c}\text { Std dev. } d \\
\%\end{array}$ \\
\hline SBB01H all & $69^{*}, 87^{\dagger}$ & -31.9 & 0.9 & -251.6 & 7.3 & 3.7 & 0.9 \\
\hline SBB01 all & 58 & -30.9 & 0.4 & -238.5 & 3.0 & 8.6 & 1.1 \\
\hline
\end{tabular}

\footnotetext{
${ }^{*}$ Number of $\delta^{18} \mathrm{O}$ samples.

Number of $\delta \mathrm{D}$ samples.
} 


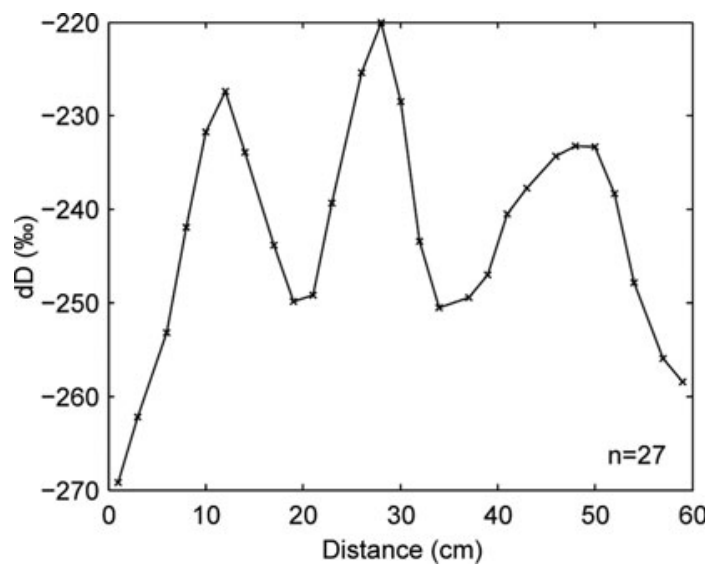

Fig. 3. Results of the high-resolution $\delta D$ analysis measured from a $60 \mathrm{~cm}$ section of the horizontal core SBB01H.

Holocene optimum and modern levels. The decreasing trends found elsewhere in East Antarctica are probably the result of an overall Holocene increase in elevation of the East Antarctic ice sheet (Masson and others, 2000), due to increased Holocene accumulation rates (Ritz and others, 2001).

The SBB01 core has a $1 \%$ higher mean value in $\delta^{18} \mathrm{O}$ (and $\sim 13 \%$ higher $\delta \mathrm{D}$ ) than the horizontal core $\mathrm{SBB} 01 \mathrm{H}$ (Table 2). The $\delta^{18} \mathrm{O}$ values of $\mathrm{SBB} 01 \mathrm{H}$ are also lower than the present-day value of $-28.5 \%$ by $\sim 3.4 \%$ ( $27 \%$ lower for $\delta \mathrm{D})$. We know that there was an elevation decrease of 200-250 $\mathrm{m}$ in Scharffenbergbotnen between the LGM and the present day (Hättestrand and Johansen, 2005), and that the elevation must have changed gradually. Thus, we use $\Delta \delta^{18} \mathrm{O}_{\mathrm{EC}}=0.6 \%$ and $\Delta \delta^{18} \mathrm{O}_{\mathrm{SW}}=0$ for mid-Holocene and present-day values. From Equation (1) we find $\Delta \delta^{18} \mathrm{O}_{\text {temp }} \approx-1.6 \pm 0.1 \%$ between SBB01 and SBB01H, and $\Delta \delta^{18} \mathrm{O}_{\text {temp }} \approx 2.8 \pm 0.2 \%$ between $\mathrm{SBB} 01 \mathrm{H}$ and the present-day samples. These changes correspond to a cooling of $\sim 1.4 \pm 0.4^{\circ} \mathrm{C}$ and warming of $\sim 2.4 \pm 2.0^{\circ} \mathrm{C}$, respectively.

There is a decrease of $11 \%$ in $\delta \mathrm{D}\left(1.4 \% 0\right.$ in $\left.\delta^{18} \mathrm{O}\right)$ in the last $40 \mathrm{~m}$ section at the downstream end of the $\mathrm{SBB} 01 \mathrm{H}$ isotope profile (Fig. 4b). Oerter and others (2004) found that changes in precipitation seasonality in DML can cause trends in the $\delta^{18} \mathrm{O}$ profile of $\sim 2 \%$ within a 200 year period. That and influences of many source-region climate changes, however, are unlikely for the first half of the trend $(60-80 \mathrm{~m}$ in Fig. 4) as they are expected to cause anticorrelated changes in $d$ excess with $\delta \mathrm{D}$ (Kavanaugh and Cuffey, 2003; Oerter and others, 2004). Thus, using Equation (1) we calculate that the change of $-4.6 \%$ in $\delta \mathrm{D}$ between 60 and $80 \mathrm{~m}$ (Fig. 4) corresponds to a temperature change of $\sim 0.5 \pm 0.2^{\circ} \mathrm{C}$ using the temperature-isotope relationship of Isaksson and Karlén (1994).

\subsection{Changes in blue-ice dynamics since LGM}

In this paper, we have shown that the BIA has not been in steady state throughout the Holocene. However, according to the moraine studies (Hättestrand and Johansen, 2005), the inner part of Scharffenbergbotnen was a local ablation area at the LGM because otherwise the supraglacial debris would have been transported from the valley.

The generally young age of the surface ice is the result of the past mass-balance and flow regime. We can explore some possible scenarios with a volume-conserving flow

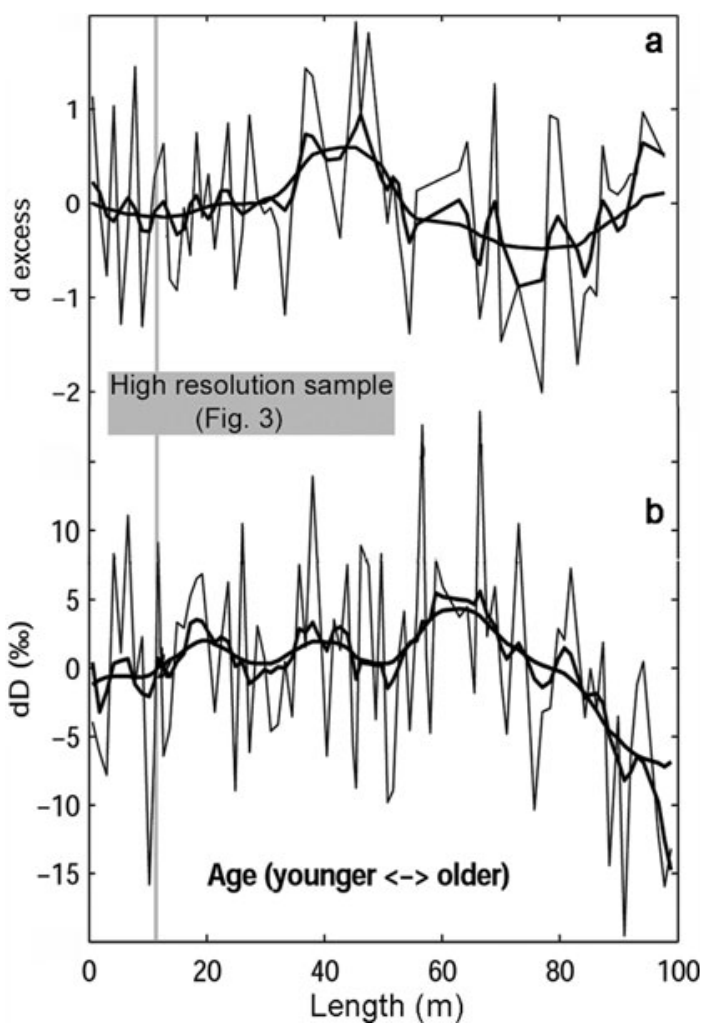

Fig. 4. The variability of $d$ excess (a) and $\delta D$ values (b) of the horizontal SBB01H core: the $d$ excess and $\delta \mathrm{D}$ records (gray), longterm trend as the first reconstructed component of the singular spectrum analysis (SSA) (e.g. Ghil and others, 2002) using an embedding dimension of 10 (thick black line), and the partial reconstruction as the sum of the first and second component of the SSA (thick gray line). SBB01H is $100 \mathrm{~m}$ long and oriented along the flowline (Fig. 1). The youngest ice is found at $x=0$. Older ice, $\sim 540$ years, is found downstream at $x=100 \mathrm{~m}$.

model that does accommodate temporally variable surface velocity, ice thickness and mass balance along the flowline with parameterized variation of ice rheology with depth to produce particle trajectories and isochrones (Grinsted and others, 2003). There is no unique solution for how the BIA has changed over the last glacial cycle as there are only very few constraints on the surface age. We study three simple cases that produce surface ice ages comparable to those calculated from ${ }^{14} \mathrm{C}$ ages (Van Roijen, 1996; Van der Kemp and others, 2002). As the most accurate ${ }^{14} \mathrm{C}$ age was measured for SBB01, we define it to be the most important age to match. The cases are:

i. different surface velocity in the past;

ii. different accumulation rate in the past;

iii. a combination of cases $\mathrm{i}$ and ii.

In the following we discuss each case in turn.

\section{i. Different horizontal ice velocity}

There must have been less inflow through the northwestern gate to the valley (Fig. 1) at the LGM than today because the surface elevation difference between the valley and its surroundings was smaller. Additionally, there must have been inflow from other directions as the ice flowed over the mountains, at least at the eastern end of the valley (Hättestrand and Johansen, 2005), though there must have 


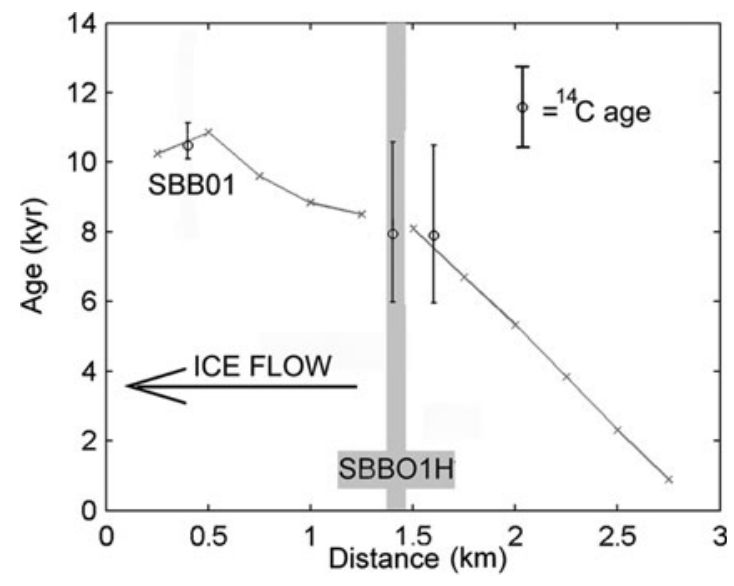

Fig. 5. The calibrated ${ }^{14} \mathrm{C}$ ages (Van Roijen, 1996; Van der Kemp and others, 2002) along the flowline (Fig. 1) and model output with a linearly changing temporal and spatial surface velocity and accumulation rate reaching the present-day values in 11000 years. The starting accumulation rate was $0.13 \mathrm{~m}$ w.e. everywhere along the flowline and the surface velocity was zero. The error bars for SBB01 are calculated using a radiocarbon calibration curve of Reimer and others (2004). Only those of the other blue-ice cores (Van Roijen, 1996) that were located within $50 \mathrm{~m}$ of the flowline were plotted. There is thus an error associated with projecting the measurements onto the flowline. The relationship between error and distance was estimated by fitting a straight line to the relative difference between two ${ }^{14} \mathrm{C}$ measurements against their distance. The horizontal distance is measured starting from the bottom of the valley. SBB01 is located at $x=400 \mathrm{~m}$ and SBB01H at $x=1400 \mathrm{~m}$.

been a net inward flow to preserve the BIA. Thus, the surface velocities must have been lower at the LGM than today.

It is not possible, however, to produce Holocene ages for SBB01 with the flow model using smaller surface velocities for the BIA in the past. On the contrary, the surface velocity would have to have been many times higher over the whole Holocene than the current measured velocity profile if it alone was responsible for the measured Holocene age. It is clear that different surface velocity alone cannot explain the young surface ice in the BIA.

The distance between SBB01 and the current equilibrium-line altitude, determined from the accumulation and ground-penetrating radar data, is $\sim 2600 \mathrm{~m}$ (Sinisalo and others, 2004). Based on the geometry, the mean surface velocity needed for an age of 10500 years BP for the SBB01 site is $0.5 \mathrm{~m} \mathrm{a}^{-1}$, if the surface velocities had been constant through time and the size of the BIA had not changed. This is $70 \%$ larger than the maximum velocity $\left(0.3 \mathrm{~m} \mathrm{a}^{-1}\right)$ that is measured in the valley (Sinisalo and others, 2003), and contradicts the evidence for lower surface velocities in the past. With a current average surface velocity of $0.14 \mathrm{~m} \mathrm{a}^{-1}$ in the valley (Sinisalo and others, 2003), the 10500 year old ice in SBB01 would have originated only $1500 \mathrm{~m}$ upstream. This is inside the present-day ablation area, so we conclude that the equilibrium line has probably moved over time and that the BIA was smaller in the past.

\section{ii. Different accumulation rate}

Many studies suggest increased accumulation in Antarctica during the Holocene in comparison with the LGM (e.g. Udisti and others, 2004). The results from the EDML core for the past 7000 years, however, show decreasing accumulation during the past 4000 years (Oerter and others, 2004).
It is only possible to produce an age of 10500 years for SBB01 with the flow model by increasing the accumulation rate earlier in the Holocene from the present observations. We get the best fit to the calibrated ${ }^{14} \mathrm{C}$ ages by adding a linear accumulation rate gradient of $2.2 \times 10^{-5} \mathrm{~m} \mathrm{a}^{-2}$ to the current measured accumulation rates at all positions along the flowline, so that the accumulation rates reach the present values in 11000 years (Sinisalo and others, 2003). The model output gives a nearly linear surface age gradient over the whole BIA of about 4 years $\mathrm{m}^{-1}$, which suggests $\mathrm{SBB} 01 \mathrm{H}$ is $\sim 6600$ years old. The horizontal age gradient of 5.4 years $\mathrm{m}^{-1}$ estimated from the $\mathrm{SBB} 01 \mathrm{H}$ high-resolution data (Fig. 3) is in reasonable agreement with the 4 years $\mathrm{m}^{-1}$ considering that only three cycles were measured isotopically, and natural accumulation variability over 3 years may typically be $30 \%$ (e.g. Isaksson and others, 1996; Sinisalo and others, 2003).

\section{iii. Different ice flow regime in the valley}

To model the scenario of both lower velocity and higher accumulation rate as suggested by the results of cases $i$ and ii, we choose to linearly change the temporal and spatial surface velocity and accumulation rate for the flow model. We assume that the whole valley was an accumulation area in the glacial period (prior to 11000 years BP) with an accumulation rate of $0.13 \mathrm{~m}$ w.e. everywhere along the flowline, and a starting velocity of zero. We let the surface velocity and the accumulation rate change linearly over time so they reach the present values at 0 years BP. This leads to an ablation area, i.e. a BIA, with surface ages matching the ${ }^{14} \mathrm{C}$ ages, even if the whole valley begins as an accumulation area and there is no inflow through the northwestern gate (Fig. 5). Of course, this scenario is not modelled realistically as the flow model is purely prescriptive, but it is included here to suggest the possibility of negligible ablation area in the last glacial period.

The best-fit model to the ${ }^{14} \mathrm{C}$ ages gives a surface age gradient of $\sim 2.8$ years $\mathrm{m}^{-1}$ between SBB01 and SBB01H. This suggests that SBB01H is about 8000 years old (Fig. 5). In general, the modelled surface age gradients agree with the earlier studies of dated GPR reflection horizons that gave values of 3-6 years $\mathrm{m}^{-1}$ at the firn/blue-ice transition zone (Sinisalo and others, 2004).

\section{CONCLUSIONS}

In this study we show that most of the main BIA in Scharffenbergbotnen is Holocene ice, based on the $\delta^{18} \mathrm{O}$ values in blue ice and snow. The $\delta^{18} \mathrm{O}$ values in SBB01 support the previous ${ }^{14} \mathrm{C}$ dating of SBB01 and rule out the possibility that the ice close to the bottom of the valley originates from the East Antarctic plateau or from a glacial period.

The oldest surface ice in the valley was found close to the moraines on the southern side of the main BIA in Scharffenbergbotnen where the $\delta^{18} \mathrm{O}$ value was most negative (sample B1 in Fig. 1). The calibrated calendar age (Reimer and others, 2004) at that part gave an age $>28000$ years BP (cf. Van Roijen, 1995: ${ }^{14} \mathrm{C}$ age $>24000$ years BP). The oldest ice may have remained at the southern margin 'isolated' from the main flow. However, there is no indication of where this ice originates.

We showed that it is possible to extract a high-resolution paleoclimate record from the BIA even with an annual resolution. However, we need a longer horizontal isotopic 
profile from the BIA in order to study how the surface age gradient varies and to determine the age of SBB01 $\mathrm{H}$ reliably.

The differences in stable-isotope values between blue-ice and firn samples imply that the modern climate is about $1.0 \pm 0.3^{\circ} \mathrm{C}$ warmer than the climate in the early-Holocene optimum in Scharffenbergbotnen. Further, the 10500 year old SBB01 originates from a warmer period than the midHolocene SBB01H.

According to our simple flow modelling it is possible that the whole of Scharffenbergbotnen was an accumulation area at the LGM. However, previous studies of supraglacial moraines and ${ }^{14} \mathrm{C}$ dating, together with $\delta^{18} \mathrm{O}$ values at the southern margin of the main BIA, indicate that the BIA existed during the LGM. Therefore we suggest that the BIA was smaller than it currently is, and that the surface velocities were considerably smaller at the LGM. The young age of the major part of the BIA also explains the lack of meteorite finds in this area, and may be typical for many BIAs in low-elevation nunatak areas, where the ice-sheet elevation changes at the glacial termination are likely to have been most pronounced (Pattyn and Decleir, 1998).

It is clear that the evolution of the BIA requires a full diagnostic flow model, and we are presently setting up a finite-element scheme solving the full polythermal Stokes equations (Le Meur and others, 2004).

\section{ACKNOWLEDGEMENTS}

We are grateful to K. Virkkunen and J. Vehviläinen for help with fieldwork and for preparing samples for analysis. We also thank the Dutch field team drilling SBB01, and the Finnish Forestry Research Institute Rovaniemi. We thank F. Vimeux and an anonymous reviewer for critical comments that improved the manuscript substantially, and D. Peel for his efforts as the Scientific Editor. The Finnish Antarctic Research Program (FINNARP 1999-2001 and 2003-04) provided field logistics. Financial support was also obtained from the Netherlands Organization for Scientific Research (NWO) by a grant of the Netherlands Antarctic Programme. The work was primarily funded by the Academy of Finland and the Thule Institute. Part of this work was also funded by the Arctic graduate school ARKTIS and by grants from the Faculty of Natural Sciences, Oulu University, and the University Pharmacy Foundation (Oulu).

\section{REFERENCES}

Bintanja, R. 1999. On the glaciological, meteorological and climatological significance of Antarctic blue ice areas. Rev. Geophys., 37(3), 337-359.

Bintanja, R. 2000a. Mesoscale meteorological conditions in Dronning Maud Land, Antarctica, during summer: a qualitative analysis of forcing mechanisms. J. Appl. Meteorol., 39(12), 2348-2370.

Bintanja, R. 2000b. The surface heat budget of Antarctic snow and blue ice: interpretation of temporal and spatial variability. J. Geophys. Res., 105(D19), 24,387-24,407.

Bintanja, R. and C.H. Reijmer. 2001. Meteorological conditions over Antarctic blue-ice areas and their influence on the local surface mass balance. J. Glaciol., 47(156), 37-50.

Bintanja, R. and M.R. van den Broeke. 1995a. The climate sensitivity of Antarctic blue-ice areas. Ann. Glaciol., 21, 157-161.

Bintanja, R. and M.R. van den Broeke. 1995b. The surface energy balance of Antarctic snow and blue ice. J. Appl. Meteorol., 34(4), 902-926.
Bintanja, R., C.H. Reijmer and S.J.M.H. Hulscher. 2001. Detailed observations of the rippled surface of Antarctic blue-ice areas. J. Glaciol., 47(158), 387-396.

Delaygue, G., J. Jouzel, V. Masson, R.D. Koster and E. Bard. 2000. Validity of the isotopic thermometer in central Antarctica: limited impact of glacial precipitation seasonality and moisture origin. Geophys. Res. Lett., 27(17), 2677-2680.

EPICA Community Members. 2006. One-to-one coupling of glacial climate variability in Greenland and Antarctica. Nature, 444(7116), 195-198.

Ghil, M. And 10 others. 2002. Advanced spectral methods for climatic time series. Rev. Geophys., 40(1), 1003. (10.1029/ 2000RG000092.)

Grinsted, A., J.C. Moore, V. Spikes and A. Sinisalo. 2003. Dating Antarctic blue ice areas using a novel ice flow model. Geophys. Res. Lett., 30(19), 2005. (10.1029/2003GL017957.)

Hättestrand, C. and N. Johansen. 2005. Supraglacial moraines in Scharffenbergbotnen, Heimefrontfjella, Dronning Maud Land, Antarctica: significance for reconstructing former blue ice areas. Antarct. Sci., 17(2), 225-236.

Helsen, M.M., R.S.W. van de Wal, M.R. van den Broeke, D. van As, H.A.J. Meijer and C.H. Reijmer. 2005. Oxygen isotope variability in snow from western Dronning Maud Land, Antarctica and its relation to temperature. Tellus, 57B(5), 423-435.

Helsen, M.M. and 6 others. 2006. Modelling the isotopic composition of Antarctic snow using backward trajectories: simulation of snow pit records. J. Geophys. Res., 111(D15), D15109. (10.1029/2005JD006524.)

Herzfeld, U.C. and P. Holmlund. 1990. Geostatistics in glaciology: implications of a study of Scharffenbergbotnen, Dronning Maud Land, East Antarctica. Ann. Glaciol., 14, 107-110.

Isaksson, E. and W. Karlén. 1994. High resolution climatic information from short firn cores, western Dronning Maud Land, Antarctica. Climatic Change, 26(4), 421-434.

Isaksson, E., W. Karlén, N. Gundestrup, P. Mayewski, S. Whitlow and M. Twickler. 1996. A century of accumulation and temperature changes in Dronning Maud Land, Antarctica. J. Geophys. Res., 101(D3), 7085-7094.

Jonsson, S. 1992. Local climate and mass balance of a blue ice area in western Dronning Maud Land, Antarctica. Z. Gletscherkd. Glazialgeol., 26(1), 11-29.

Jonsson, S. and P. Holmlund. 1990. Evaporation of snow and ice in Scharffenbergbotnen, Dronning Maud Land, Antarctica. Ann. Glaciol., 14, 342-343.

Jouzel, J. and 6 others. 2003. Magnitude of isotope/temperature scaling for interpretation of central Antarctic ice cores. J. Geophys. Res., 108(D12), 4361-4370.

Kavanaugh, J.L. and K.M. Cuffey. 2003. Space and time variation of $\delta^{18} \mathrm{O}$ and $\delta \mathrm{D}$ in Antarctic precipitation revisited. Global Biogeochem. Cycles, 17(1), 1017. (10.1029/2002GB001910.)

Labeyrie, L.D., J.C. Duplessy and P.L. Blanc. 1987. Variations in mode of formation and temperature of oceanic deep waters over the past 125,000 years. Nature, 327(6122), 477-482.

Le Meur, E., O. Gagliardini, T. Zwinger and J. Ruokolainen. 2004. Glacier flow modelling: a comparison of the Shallow Ice Approximation and the full-Stokes equation. C.R. Phys., 5(7), 709-722.

Lintinen, P. and J. Nenonen. 1997. Glacial history of the Vestfjella and Heimefrontfjella nunatak ranges in western Dronning Maud Land, Antarctica. In Ricci, C.A., ed. The Antarctic region: geological evolution and processes. Siena, Università degli Studi di Siena, 845-852.

Lorius, C. and L. Merlivat. 1977. Distribution of mean surface stable isotope values in East Antarctica: observed changes with depth in the coastal area. IAHS Publ. 118 (Symposium at Grenoble 1975 - Isotopes and Impurities in Snow and Ice), 127-137.

Masson, V. and 13 others. 2000. Holocene climate variability in Antarctica based on 11 ice-core isotopic records. Quat. Res., 54(3), 348-358. 
Merlivat, L. and J. Jouzel. 1979. Global climatic interpretation of the deuterium-oxygen 18 relationship for precipitation. J. Geophys. Res., 84(C8), 5029-5033.

Moore, J.C. and 7 others. 2006. Interpreting ancient ice in a shallow ice core from the South Yamato (Antarctica) blue ice area using flow modeling and compositional matching to deep ice cores. J. Geophys. Res., 111(D16), D16302. (10.1029/2005JD006343.)

Nishiizumi, K., D. Elmore and P.W. Kubik. 1989. Update on terrestrial ages of Antarctic meteorites. Earth Planet. Sci. Lett., 93(3-4), 299-313.

Oerter, H., W. Graf, H. Meyer and F. Wilhelms. 2004. The EPICA ice core from Dronning Maud Land: first results from stableisotope measurements. Ann. Glaciol., 39, 307-312.

Pattyn, F. and H. Decleir. 1998. Ice dynamics near Antarctic marginal mountain ranges: implications for interpreting the glacial-geological evidence. Ann. Glaciol., 27, 327-332.

Petit, J.R., J.W.C. White, N.W. Young, J. Jouzel and Y. Korotkevich. 1991. Deuterium excess in recent Antarctic snow. J. Geophys. Res., 96(D3), 5113-5122.

Petit, J.R. and 18 others. 1999. Climate and atmospheric history of the past 420,000 years from the Vostok ice core, Antarctica. Nature, 399(6735), 429-436.

Popp, T., T. Sowers, N. Dunbar, W. Mclntosh and J.W.C. White. 2004. Radioisotopically dated climate record spanning the last interglacial in ice from Mount Moulton, West Antarctica.

Reijmer, C.H. 2001. Antarctic meteorology: a study with automatic weather stations. (PhD thesis, University of Utrecht.)

Reijmer, C.H. and M.R. van den Broeke. 2003. Temporal and spatial variability of the surface mass balance in Dronning Maud Land, Antarctica, as derived from automatic weather stations. J. Glaciol., 49(167), 512-520.

Reimer, P.J. and 27 others. 2004. IntCal04 terrestrial radiocarbon age calibration, 0-26 cal kyr BP. Radiocarbon, 46, 1029-1058.

Ritz, C., V. Rommelaere and C. Dumas. 2001. Modeling the evolution of Antarctic ice sheet over the last 420,000 years: implications for altitude changes in the Vostok region. J. Geophys. Res., 106(D23), 31,943-31,964.

Sinisalo, A., J.C. Moore, R.S.W. van de Wal, R. Bintanja and S. Jonsson. 2003. A 14 year mass-balance record of a blue-ice area in Antarctica. Ann. Glaciol., 37, 213-218.

Sinisalo, A., A. Grinsted and J. Moore. 2004. Dynamics of the Scharffenbergbotnen blue-ice area, Dronning Maud Land, Antarctica. Ann. Glaciol., 39, 417-422.

Udisti, R. and 8 others. 2004. Stratigraphic correlation between the
EPICA-Dome $\mathrm{C}$ and Vostok ice cores showing the relative variations of snow accumulations over the past $45 \mathrm{kyr}$. J. Geophys. Res., 109(D8), D08101. (10.1029/2003JD004180.)

Van den Broeke, M.R. and R. Bintanja. 1995. The interaction of katabatic winds and the formation of blue-ice areas in East Antarctica. J. Glaciol., 41(138), 395-407.

Van der Kemp, W.J.M. and 7 others. 2002. In situ produced ${ }^{14} \mathrm{C}$ by cosmic ray muons in ablating Antarctic ice. Tellus, $\mathbf{5 4 B}(2)$, 186-192.

Van Lipzig, N.P.M., E. van Meijgaard and J. Oerlemans. 2002. The effect of temporal variations in the surface mass balance and temperature-inversion strength on the interpretation of ice-core signals. J. Glaciol., 48(163), 611-621.

Van Roijen, J.J. 1996. Determination of ages and specific mass balances from ${ }^{14} \mathrm{C}$ measurements on Antarctic surface ice. (PhD thesis, Utrecht University.)

Van Roijen, J.J., R. Bintanja, K. Van der Borg, M.R. van den Broeke, A.F.M. De Jong and J. Oerlemans. 1994. Dry extraction of ${ }^{14} \mathrm{CO}_{2}$ and ${ }^{14} \mathrm{CO}$ from Antarctic ice. Nucl. Instrum. Meth. Phys. Res. B, 92(1-4), 331-334.

Van Roijen, J.J., K. Van der Borg, A.F.M. De Jong and J. Oerlemans. 1995. Ages, ablation and accumulation rates from ${ }^{14} \mathrm{C}$ measurements on Antarctic ice. Ann. Glaciol., 21, 139-143.

Vimeux, F., V. Masson, G. Delaygue, J. Jouzel, J.R. Petit and M. Stievenard. 2001. A 420000 year deuterium excess record from East Antarctica: information on past changes in the origin of precipitation at Vostok. J. Geophys. Res., 106(D23), 31,863-31,873.

Vimeux, F., K.M. Cuffey and J. Jouzel. 2002. New insights into Southern Hemisphere temperature changes from Vostok ice cores using deuterium excess correction. Earth Planet. Sci. Lett., 203(4), 829-843.

Waelbroeck, C. and 7 others. 2002. Sea-level and deep water temperature changes derived from benthic foraminifera isotopic records. Quat. Sci. Rev., 21(1-3), 295-305.

Werner, M., M. Heimann and G. Hoffmann. 2001. Isotopic composition and origin of polar precipitation in present and glacial climate systems. Tellus, 53B(1), 53-71.

Whillans, I.M. and W.A. Cassidy. 1983. Catch a falling star: meteorites and old ice. Science, 222(4619), 55-57.

Wilch, T.I., W.C. McIntosh and N.W. Dunbar. 1999. Late Quaternary volcanic activity in Marie Byrd Land: potential ${ }^{40} \mathrm{Ar} /{ }^{39} \mathrm{Ar}$ dated time horizons in West Antarctic ice and marine cores. Geol. Soc. Am. Bull., 111(10), 1563-1580. 